\title{
Assistance to the Faculty in Library Research: Report from Cornell University
}

Dr. King is faculty research assistant, Cornell University Library.

$\mathrm{T}$ HE WORK of the faculty research assistant in the Cornell University $\mathrm{Li}$ brary had its inception in 1932 , when the Carnegie Corporation, acting upon the suggestion of Professor Harlow Shapley, of Harvard University, supplied funds to Cornell and one or two other universities for experimentation in what was called the research librarianship. The function then contemplated, and largely maintained to the present day, involved employment in the university library of one whose sole purpose should be to assist members of the faculty in the preparation of scholarly works designed for publication in the fields of the humanities and the social sciences.

The scope and diversity of the activities carried on at Cornell for the past fifteen or sixteen years can best be indicated by the following list of the principal works published during that period in which there is prefatory or other acknowledgment of the aid or collaboration of the research assistant.

1934. Caplan, Harry. Mediaeval Artes Praedicandi: a Hand-List. Ithaca, N.Y., Cornell University Press

1935. Stephenson, Carl. Mediaeval History; Europe from the Fourth to the Sixteenth Century. New York and London, Harper and Brothers

1936. Caplan, Harry. Mediaeval Artes
Praedicandi: a Supplementary Hand-List. Ithaca, N.Y., Cornell University Press 1937. Johnson, Edgar Augustus Jerome. Predecessors of Adam Smith; the Growth of British Economic Thought. N.Y., PrenticeHall, Inc.

Stephenson, Carl, and Frederick George Marcham, editors and translators. Sources of English Constitutional History; a Selection of Documents from A.D. 600 to the Present. New York and London, Harper and Brothers

Marcham, Frederick George. A History of England. N.Y., Macmillan Company

1939. Laistner, M. L. W., editor. Bedae Venerabilis Expositio Actuum Apostolorum et Retractatio. Cambridge, Mass., Mediaeval Academy of America

Jones, Charles W. Bedae Pseudepigrapha; Scientific Writings Falsely Attributed to Bede. Ithaca, N.Y., Cornell University Press

194I. Cushman, Robert Eugene. The Independent Regulatory Commissions. N.Y., London, etc., Oxford University Press

Stephenson, Carl. A Brief Survey of $\mathbf{M e -}$ diaeval Europe. New York and London, Harper and Brothers

1942. Adelmann, Howard B., editor and translator. The Embryological Treatises of Hieronymus Fabricius of Aquapendente. Ithaca, N.Y., Cornell University Press

1943. Laistner, M. L. W. A Hand-List of Bede Manuscripts, by M. L. W. Laistner, ... with the collaboration of H. H. King. Ithaca, N.Y., Cornell University Press

George Lincoln Burr: His life by Roland H. Bainton; selections from his writings edited by Lois Oliphant Gibbons; bibliography compiled by Henry H. King. Ithaca, N.Y., Cornell University Press 
Jones, Charles W., editor. Bedae Venerabilis Opera de Temporibus. Cambridge, Mass., Mediaeval Academy of America

1946. Hutton, James. The Greek Anthology in France and in the Latin Writers of the Netherlands to the Year I80o. Ithaca, N.Y., Cornell University Press

1947. Jones, Charles W. Saints' Lives and Chronicles in Early England. Ithaca, N.Y., Cornell University Press

Schneider, Heinrich. Quest for Mysteries. The Masonic Background for Literature in Eighteenth-Century Germany. Ibid.

\section{Manuscript Bibliography}

Even a cursory reading of the foregoing list will reveal the impossibility of generalizing upon methods and results. There has, however, been a preponderance of bibliographical work. The compiling of a list of manuscripts of the Venerable Bede is an example of a long-term bibliographical quest. The bulk of the collection, as Professor Laistner remarks in the preface to his Hand-List of Bede Manuscripts, was "gradually compiled" through a period of cight or nine years. According to a reviewer in The Journal of Theological Studies, this volume lists about 1545 manuscripts containing works of Bede. In addition to systematic examination of the not inconsiderable collection of manuscript catalogs in the library of Cornell University, a few weeks' supplementary study was made of catalogs in the Widener Library, Harvard University. Two by-products of this search should be mentioned. The principal one is a typed list of the manuscript catalogs in the Cornell University Library containing titles of manuscripts of the Church Fathers. This list has been bound in two volumes (I. Local List, II. General List) and is accessible to users of the library who are interested in Latin manuscripts in general or in the special field embraced by the list. A second list comprises the more important catalogs not in the library's possession. This has also proved helpful to readers and to the library administration as a guide to the purchase of additional catalogs.

Another project that involved examination of catalogs of Latin manuscripts was that of assistance to Professor Harry Caplan in supplementation of studies made by him in European libraries for his handlists of mediaeval artes praedicandi. This study of catalogs available in the Cornell University Library was also supplemented by work at the Widener Library. Since publication of these lists, Professor Caplan has set about bringing down to date the listing of technical works on preaching. This demands a project of considerably longer duration than the quest of Bede manuscripts and is expected to produce a series of published lists, beginning probably with a Rhetorica Sacra Latina, to be followed by English, French, German, Dutch, Spanish, Italian lists, and so forth; for inasmuch as the mediaeval artes praedicandi were international in origin, continuation of the study into modern times leads naturally to a multilingual bibliography.

\section{Political Science and History}

A quite different type of research was used in the investigations made for Professor Cushman's book on The Independent Regulatory Commissions. These entailed a search of the Congressional Record from the creation of the Interstate Commerce Commission in 1887 for discovery of all material vital to a thorough treatment of the subject. The resultant assemblage was enormous. The undertaking consumed more than a year of the research assistant's time.

Another type of project appeared in Professor Carl Stephenson's Mediaeval History and his Brief Survey of Mediaeval Europe. The nature of the work is indi- 
cated most generously in each of the author's prefaces, in the former of which he writes: "Mr. H. H. King, Faculty Research Assistant in the Cornell University Library, has devoted weeks of painstaking labor to the verification of names, dates, titles of books, and other details throughout the whole volume. He has saved me from dozens of mistakes, big and little." Each of these was a short-term task, characterized by the stress typical of the period immediately preceding an author's going to press.

\section{Science}

The assistance rendered in the preparation of the edition of The Embryological Works of Hieronymus Fabricius, slight when contemplated in relation to the book as a whole, was mainly threefold in character: bibliographical, historical, and analytical. It proved possible to add but relatively little to the bibliography which Professor Adelmann had already compiled. The historical part of the project concerned the exceedingly florid dedication of his De Formato Fetu which Fabricius addresses "to the most illustrious and eminent Renatus Borromaeus, Count of Arona." He traces that count's ancestry back to the Roman emperor Aulus Vitellius, and proceeds with fulsome attention to the achievements and virtues, real or mythical, of intermediate progenitors from that era to I606, the date of the dedication. The opportunity for historical research provided by this brief section of the book is testified to by the forty-four explanatory footnotes to the nine pages it covers. The analytical work was connected with the seventy-page index. The subject matter is such, however, that the only contribution possible was more in the nature of labor than of analysis, consisting mainly in the assembling of a relatively unorganized mass of items upon which the translator and editor himself performed the needful analytical processes.

\section{Bibliography}

The bibliography of the writings of the late Professor George Lincoln Burr deviates somewhat from the normal pattern. It is an independent portion of a book and in its entirety the work of the research assistant.

\section{Background Studies}

The six projects described in some detail show the general nature and scope of the work done. Two projects not undertaken with a view to publication are sufficiently significant to deserve mention here.

One is an index of British Parliamentary Debates $1814-1840$. The cards comprising it fill twenty standard-size filing drawers. Recording the contents of ninety-five volumes, this index required a number of years work, interspersed, of course, with numerous other quests and studies.

Another of these undertakings was a study of the proportionate distribution among the different languages of the writings on physics, chemistry, engineering, geology, and plant science published in the years 1915 and 1935. This formidably statistical project was taken on at the request of the late Floyd K. Richtmyer, dean of the graduate school, and completed at the wish of his successor, Professor George H. Sabine. Its purpose was to afford guidance in the modification of language study prerequisites for graduate students in the different scientific fields represented in the survey.

\section{Organization}

Something should be said about the modus operandi of all this diversity. There has been a minimum of organization. 
Throughout the project the faculty member employing assistance is in close touch with the research assistant, except in certain long-term operations the pattern of which is established early. Experience has shown that at the beginning of the collaboration men desiring research assistance almost invariably give very definite instructions, the following of which leads naturally to the uncovering of additional sources and ramifications of the subject. Indeed, one of the chief dangers lies in the constant widening and branching out of the trail of library research, which may easily lead too far afield unless frequent contact with the originator restricts the project to the limits he has set himself.

The question of control has not proved a formidable one. When the relationship was first entered upon in 1932, the research assistant was admonished to avoid being monopolized. Time must be divided among the projects in hand at any one period, with reasonable exceptions, of course, as when approaching publication date might necessitate temporarily exclusive concentration upon a single undertaking. The plan proved workable because there never was a time when no work was in hand and never a time also when pressure of previous commitments compelled refusal of one more.

Last year a larger measure of organization was introduced. By the new arrangement each applicant for assistance submits his request to the dean of the graduate school with a statement of the amount of time he estimates that his project will require. The dean of the graduate school confers with a committee on research, of which he is chairman, as to the eligibility of all such requests, and communicates to the director of the university library the findings of that committee. Since all requests are received at semiannual intervals, in May and in November, the time of the research assistant is constantly scheduled. Contacts between faculty members and the research assistant are as close and direct as under the original plan of action.

It has been a constant source of inspiration to associate one's labors with those of men of so high scholarly attainment, and the opportunity of being in any measure helpful to them in the preparation of their published works is counted by the present writer as one of the greatest privileges of his life.

\section{Graduate Library School Institute}

The Graduate Library School of the University of Chicago will present its thirteenth annual institute, August I6-2 I, I 948. The topic is "Education for Librarianship."

The program will consist of four major topics: ( I ) "General Orientation," to be discussed by Ernest C. Colwell, Ralph W. Tyler, Helen R. Wright, Louis R. Wilson, Harold Lancour, Leon Carnovsky, and Lawrence S. Thompson; (2) "Preparatory Education," to be discussed by Clarence $\mathrm{H}$. Faust and Louis S. Shores; (3) "Professional Education for Librarianship," to be discussed by Ralph Munn, Richard H. Sealock, Lawrence Clark Powell, B. Lamar Johnson, Ruth Ersted, Mildred L. Batchelder, Herman H. Henkle, Rose L. Vormelker, and Neil C. Van Deusen; and (4) "Special Problems," to be discussed by Bernard Berelson, Robert B. Downs, Errett W. McDiarmid, Alice Lohrer, Harriet E. Howe, Carl M. White, and Anita Hostetter. On Saturday, August 21, general summaries of the papers and discussions will be presented by Robert D. Leigh, Luther $H$. Evans, and J. Periam Danton. 